\title{
ANALISIS PENGARUH PERSEPSI MAHASISWA PADA UNSUR-UNSUR BAURAN PEMASARAN TERHADAP KEPUTUSAN MAHASISWA MEMILIH PERGURUAN TINGGI IPWIJA PROGRAM S2 (PASCA SARJANA)
}

\author{
Juli Ismanto \\ Program Studi Megister Manajemen IPWI Jakarta \\ july.ismanto@gmail.com
}

\begin{abstract}
The development of the university or college that exist today provide clear evidence that the benefits of their education services not only enjoyed or felt by dealing directly with education services, but also enjoyed by all members of society. Selecting a part of the decision-making process (decision making).Impact determination of choice will be a good influence in the short term and the long term, either in the form of benefits and risks that must be borne. Moreover, the establishment choice in choosing a college is a decision that affects a person's future.Higher education service users (students) can choose many educational alternatives what's right for them, where prospective students pay attention to the educational model and how soon after they graduated from college. In order to further increase public interest in the education services on offer, it is necessary to optimize the marketing management better include education marketing performance, supported by an effective marketing strategy. One step that can be done is to find out the marketing mix variables are most affects students or prospective students as consideration in choosing a university or college. In this study, the variable student's perception on the elements of the marketing mix used to measure students choose college decision IPWIJA S2 program (Post Graduate). The object of this research is that students IPWIJA S2 program (Post Graduate). Quantitative Analysis in the research carried out to test the reliability, validity, classic assumption (consisting of test muultikolineritas, normality test, and test hetrokedasitas), multiple linear regression analysis, goodness of fit test (consisting of the coefficient of determination, $F$ test and $t$ test), while the qualitative analysis obtained from the interpretation of the respondents. The results showed that the product, pricing, promotion, location, facilities, processes, alumni, reputation, and positive influence on the motivation of the students choose college decision IPWIJA S2 program (Post Graduate).
\end{abstract}

Keywords: Product, Cost, Promotions, location, facilities, processes, Alumni, Reputation, and Motivation

Available at:

http://journal.unj.ac.id/unj/index.php/econosains/article/view/1107 


\section{PENDAHULUAN}

Pembangunan pendidikan adalah upaya mewujudkan amanat Pembukaan UUD 1945, yaitu memajukan kesejahteraan umum dan mencerdaskan kehidupan bangsa, serta ikut melaksanakan ketertiban dunia. Sesuai dengan UUD 1945 pasal 27, pendidikan mrupakan hak setiap warga negara Indonesia dimana pelaksanaannya diselenggarakan melalui Sistem Pendidikan Nasional, yang menyatakan bahwa masyarakat sebagai mitra pemerintah berkesempatan yang seluas-luasnya untuk berperan serta dalam penyelenggaraan pendidikan nasional. Salah satu wujud dari penyelenggaraan pendidikan nasional adalah adanya perguruan tinggi. Globalisasi telah mendorong timbulnya persaingan yang sangat kompetitif dalam dunia jasa pendidikan, sehingga membawa konsekuensi hanya universitas ataupun Perguruan Tinggi yang mempunyai kemampuan bersaing yang dapat bertahan dan menacapai target yang telah ditetapkan. Kemampuan bersaing tersebut, sangat dipengaruhi oleh kinerja manajemen pemasaran perusahaan bersangkutan, khususnya dalam merencanakan strategi yang berorientasi pada upaya membangun daya saing yang tinggi. Pada saat ini universitas yang ada saling berlomba untuk dapat mengembangkan seluruh potensi dan kemampuannya untuk menarik minat calon mahasiswa.

Tabel 1.1 Indikator Pendidikan Tinggi di Indonesia

\begin{tabular}{|l|c|c|c|}
\hline \multicolumn{1}{|c|}{ Indikator } & PTN & PTS & Total \\
\hline Jumlah Mahasiswa & 907.323 & 2.298 .830 & 3.206 .153 \\
\hline Jumlah Lulusan & 106.026 & 233.522 & 339.548 \\
\hline Jumlah Mahasiswa Baru & 55.225 & 212.864 & 268.089 \\
\hline Jumlah Dosen & 62.084 & 114.527 & 176.611 \\
\hline Jumlah Lembaga PT & 83 & 3.019 & 3.102 \\
\hline Jumlah Program Studi & 3.102 & 12.639 & 15.741 \\
\hline Rasio Mahasiswa / PT & 10.932 & 761 & 1.034 \\
\hline Rasio Mahasiswa / Dosen & 15 & 20 & 18 \\
\hline Rasio Mahasiswa Baru / PT & 665 & 71 & 86 \\
\hline Rasio Dosen / PT & 748 & 38 & 57 \\
\hline Rasio Lulusan / Dosen & 2 & 2 & 2 \\
\hline AEE & 12 & 10 & 11 \\
\hline Sumber : Suharyadi (2012) & & & \\
\end{tabular}


Tabel 1.2 Penduduk Usia 15 tahun keatas yang Bekerja menurut Pendidikan Tinggi yang

ditamatkan, 2011-2012 (ribuan Orang)

\begin{tabular}{|c|c|c|c|c|c|c|}
\hline \multirow[b]{2}{*}{$\begin{array}{c}\text { Pendidikan Tinggi yang di } \\
\text { Tamatkan }\end{array}$} & \multicolumn{3}{|c|}{01 Februari 2011} & \multicolumn{3}{|c|}{01 Februari 2012} \\
\hline & $\begin{array}{c}\text { Laki- } \\
\text { Laki }\end{array}$ & Perempuan & Jumlah & $\begin{array}{c}\text { Laki- } \\
\text { Laki }\end{array}$ & Perempuan & Jumlah \\
\hline 1 & 2 & 3 & 4 & 5 & 6 & 7 \\
\hline SD Kebawah & 471,40 & 403,43 & 874,83 & 500,09 & 438,56 & 938,65 \\
\hline SLTP & 414,31 & 346,57 & 760,88 & 442,91 & 302,23 & 745,14 \\
\hline SMA Umum & 816,94 & 271,66 & $1.088,60$ & 749,25 & 337,78 & $1.087,03$ \\
\hline Sma KeJuruan & 579,88 & 268,94 & 848,82 & 537,83 & 281,16 & 818,99 \\
\hline Diploma dan Universitas & 513,58 & 380,43 & 894,01 & 683,11 & 443,79 & $1.126,90$ \\
\hline Jumlah & $2.796,11$ & $1.671,03$ & $4.467,14$ & $2.913,19$ & $1.803,52$ & $4.716,71$ \\
\hline
\end{tabular}

Sumber http://www.jakarta.go.id/web/news/2012/05/keadaan-ketenagakerjaan-di-dki-jakarta-februari2012

Perkembangan universitas ataupun Perguruan Tinggi yang ada dewasa ini memberikan bukti yang nyata bahwa manfat adanya jasa pendidikan tidak hanya dinikmati atau dirasakan oleh yang berhubungan langsung dengan jasa pendidikan, tetapi juga dinikmati oleh seluruh anggotamasyarakat. Memilih merupakan bagian dari proses pengambilan keputusan (decision making). Dampak penentuan pilihan akan membawa pengaruh baik dalam jangka pendek maupun panjang, baik berupa keuntungan yang diperoleh maupun resiko yang mesti ditanggung. Terlebih lagi penetapan pilihan dalam memilih perguruan tinggi merupakan keputusan yang berdampak pada masa depan seseorang. Pengguna jasa pendidikan tinggi (mahasiswa) dapat memilih banyak alternatif pendidikan apa yang pas bagi mereka, dimana para calon mahasiswa memperhatikan model pendidikan dan bagaimana kelak setelah lulus kuliah. Pemasaran (marketing) menempati posisi yang stratgis dalam aktifitas suatu organisasi. Strategi pemasaran direncanakan dan dirancang secara khusus oleh manajemen universitas untuk menghasilkan target yang optimal. Secara awam memang istilah pemasaran sering diartikan hanya sebatas aktifitas "menjual" saja, tanpa dipahami bahwa sebenarnya banyak faktor yang melingkupi dan mempengaruhi aktifitas pemasaran. Faktor-faktor penting dari pemasaran tersebut adalah bauran pemasaran (marketing mix) yaitu seperangkat variabel terkontrol yang digunakan oleh perusahaan untuk mencapai pasar sasaran.

Perencanaan strategi marketing mix selain untuk meningkatkan penjualan seringkali juga dilakukan

Available at:

http://journal.unj.ac.id/unj/index.php/econosains/article/view/1107 
untuk mengestimasi kekuatan lawan dalam persaingan produk atau jasa sejenis. Agar dapat lebih meningkatkan minat masyarakat terhadap jasa pendidikan yang ditawarkan, yang dapat memaksimalkan target seperti yang ditetapkan atau diharapkan, maka yang perlu diperhatikan universitas adalah dengan lebih mengoptimalkan pada manajemen pemasaran yang lebih baik meliputi kinerja pemasaran perusahaan yang didukung oleh strategi pemasaran yang efektif. Dan salah satu langkah yang dapat dilakukan adalah dengan mencari tahu, variabel bauran pemasaran manakah yang paling mempengaruhi mahasiswa atau calon mahasiswa sebagai bahan pertimbangan dalam memilih universitas.

Dengan mengetahui variabel bauran pemasaran yang paling memepengaruhi keputusan mahasiswa, maka universitas dalam menetapkan strategi pemasarannya dapat lebih difokuskan, akan tetapi tidak mengesampingkan variabel bauran pamasaran lainnya, yang sedikit banyak tentunya juga mempengaruhi keputusan konsumen. Berkaitan dengan hal tersebut di atas, maka peneliti berminat untuk meneliti lebih lanjut tentang bauran pemasaran yang sudah dijalankan oleh universitas terhadap mahasiswa dan menuliskannya dalam laporan akhir berjudul: "Analisis Variabel-variabel Bauran Pemasaran yang Mempengaruhi Perilaku Mahasiswa dalam Memilih Program Pascasarjana IPWIJA". Berdasarkan uraian diatas, penulis tertarik untuk mengkaji kembali mengenai "Bagaimana Pengaruh Strategi Bauran Pemasaran Jasa yang terdiri dari: Produk/Program Studi, Harga/Uang SPP, Promosi, Lokasi, Orang, Proses, dan Pelayanan terhadap keputusan mahasiswa memilih Program Pasca Sarjana IPWIJA"

Tujuan Penelitian ini adalah:

1) Untuk mengetahui dan menganalisis pengaruh strategi bauran pemasaran jasa yang terdiri dari produk (Program Studi), harga (Uang SPP), promosi, lokasi, orang, proses, dan pelayanan terhadap keputusan mahasiswa memilih Perguruan Tinggi IPWIJA Program S2 (Pasca Sarjana)

2) Untuk mengetahui dan menganalisis faktor mana yang paling berpengaruh dari strategi bauran pemasaran jasa yang terdiri dari produk (Program Studi), harga (Uang SPP), promosi, lokasi, orang, proses, dan pelayanan terhadap keputusan mahasiswa memilih Perguruan Tinggi IPWIJA Program S2 (Pasca Sarjana)

\section{KAJIAN PUSTAKA}

Menurut Kotler persepsi adalah proses yang digunakan oleh individu untuk memilih, mengorganisasi dan menginterpretasi masukan informasi guna menciptakan gambaran dunia yang memiliki arti. Persepsi tidak hanya bergantung pada rangsangan fisik, tapi juga pada rangsangan yang 
berhubungan dengan lingkungan sekitar dan keadaan individu yang bersangkutan (Kotler, 2006).

Dalam pemasaran, persepsi itu lebih penting daripada realitas, karena persepsi itulah yang akan memengaruhi perilaku actual konsumen. Orang dapat memiliki persepsi yang berbeda atas objek yang sama karena tiga proses persepsi yaitu sebagai berikut :

1) Perhatian Selektif, adalah proses menyaring rangsangan yang di terima oleh seseorang, sehingga pemasar seharusnya dapat bekerja keras dalam rangka menarik perhatian konsumen.

2) Distorsi Selektif, adalah kecenderungan menafsirkan informasi sehingga sesuai dengan prakonsepsi kita. Konsumen akan sering memelintir informasi sehingga menjadi konsisten dengan keyakinan awal mereka atas merek dan produk.

3) Ingatan Selektif, orang akan melupakan banyak hal yang mereka pelajari, tapi cenderung mengingat informasi yang mendukung pandangan dan keyakinan mereka karena adanya ingatan selektif.

Memahami persepsi konsumen adalah penting bagi para pemasar dan produsen. Dua orang konsumen yang menerima dan memperhatikan suatu stimulus yang sama, mungkin akan mengartikan stimulus tersebut berbeda. Bagaimana seseorang memahami stimulus akan sangat dipengaruhi oleh nilai-nilai, harapan dan kebutuh- annya, yang sifatnya sangat individual (Sumarwan, 2002).

Dimana keterlibatan konsumen mengacu pada tingkat kepentingan pribadi yang dirasakan dan atau minat terhadap rangsangan yang muncul. Keterlibatan situasional bersifat jangka pendek; keterlibatan ini berubah sejalan dengan perubahan pihak yang terlibat, produk, situasi, atau komunikasi (Mowen, 2002).

\section{Stimulus Pemasaran dan Persepsi Konsumen}

Menurut Sutisna (2003), stimuli atau stimulus adalah setiap bentuk fisik, visual atau komunikasi verbal yang dapat mempengaruhi tanggapan individu. Dua tipe stimuli penting yang dapat mempengaruhi perilaku konsumen adalah pemasaran dan lingkungan (sosial dan budaya).

Stimuli pemasaran adalah setiap komunikasi atau stimuli fisik yang didesain untuk mempengaruhi konsumen. Produk dan komponenkomponennya adalah stimuli utama (primary/intrinsic stimuli). Komunikasi yang didesain untuk mempengaruhi perilaku konsumen adalah stimuli tambahan (secondary stimuli) yang mempresentasikan produk seperti kata-kata, gambar, dan simbol atau melalui stimuli lain yang diasosiasikan dengan produk seperti harga, tempat pemasaran produk, dan pengaruh kinerja pemasar.

Ada dua faktor kunci yang menentukan stimuli akan dirasakan 
dan bagaimana stimuli itu dipersepsi. Pertama, karakteristik stimulus, dan kedua, kemampuan konsumen untuk merasakan stimulus. Dua faktor yang mempengaruhi itu akan berinteraksi dalam menentukan persepsi konsumen.

\section{Bauran Pemasaran Jasa}

Marketing mix merupakan salah satu strategi pemasaran yang paling banyak digunakan oleh pemasar (marketer). Strategi ini tidak hanya diaplikasikan pada bisnis produk dan jasa semata, tetapi dapat diterapkan pada model pengelolaan perguruan tinggi yang dimasukan ke dalam model bisnis jasa (Sembiring, 2009). Selain itu, kualitas dalam jasa adalah faktor terpenting sebagai kondisi dinamis yang berhubungan dengan produk, jasa, manusia, proses dan lingkungan yang memenuhi atau melebihi harapan (Sembiring, 2009). Lebih lanjut, marketing mix memiliki pengaruh positif dan signifikan terhadap kualitas jasa (Sembiring, 2009). Mc Carthy dalam Dharmmesta, membagi kombinasi aspek-aspek strategi pemasaran atau yang lebih dikenal dengan sebutan $4 \mathrm{P}$ dari marketing mix (Dharmmesta, Manajemen Pemasaran Analisa Prilaku Konsumen, 1997).

Aspek-aspek 4 P dapat dilihat pada Tabel 1.3.

Tabel 3.1. Perincian $4 \mathrm{P}$ dari Marketing Mix.

\begin{tabular}{|c|c|c|c|}
\hline Product (Produk) & Place (Sistem Distribusi) & $\begin{array}{c}\text { Promotion } \\
\text { (Kegiatan Distribusi) }\end{array}$ & Price (harga) \\
\hline $\begin{array}{lll}\checkmark & \text { Kualitas } & \\
\checkmark & \text { Feature dan } \\
& \text { Style } \\
\checkmark & \text { Merk dan } \\
& \text { Kemasan } \\
\checkmark & \text { Product Line } \\
\checkmark & \text { Tingkat dan } \\
& \text { Pelayanan }\end{array}$ & $\begin{array}{ll}\checkmark & \text { Saluran Distribusi } \\
\checkmark & \text { Jangkauan } \\
& \text { distribusi } \\
\checkmark & \text { Lokasi Penjualan } \\
\checkmark & \text { Pengangkutan } \\
\checkmark & \text { Penggudangan }\end{array}$ & $\begin{array}{cl}\checkmark & \text { Periklanan } \\
\checkmark & \text { Personal } \\
& \text { selling } \\
\checkmark & \text { Promosi } \\
& \text { Penjualan } \\
\checkmark & \text { Publisitas }\end{array}$ & $\begin{array}{ll}\checkmark & \text { Tingkat harga } \\
\checkmark & \text { Potongan } \\
& \text { Harga } \\
\checkmark & \text { Waktu } \\
& \text { Pembayaran } \\
\checkmark & \text { Syarat } \\
& \text { pembayaran } \\
\checkmark & \text { Cadangan }\end{array}$ \\
\hline
\end{tabular}

Dari tabel 1.3 di atas dapat disimpulkan bahwa marketing mix (4 P) terdiri dari product, place, promotion, dan price. Santon dalam Dharmmesta, (Dharmmesta, Manajemen Pemasaran Analisa Prilaku Konsumen, 1997) mendefinisikan marketing mix sebagai: kombinasi dari empat variabel atau kegiatan inti dari sistem pemasaran perusahaan yang terdiri dari $4 \mathrm{P}$ dan tiap bagian dari marketing mix tersebut merupakan variabel-variabel terkendali (control/abe) yang dapat digunakan perusahaan untuk mempengaruhi tanggapan konsumen dari segmen pasar tertentu yang dituju peru- 
sahaan (Dharmmesta, Manajemen Pemasaran Analisa Prilaku Konsumen, 1997).

Aspek-aspek $4 \quad \mathrm{P}$ sangat menunjang keberhasilan sebuah perusahaan dalam mencapai tujuan yang ditargetkan. Selain untuk mendukung aktifitas manajemen, maka diperlukan tambahan variabel yang khusus menangani model bisnis jasa. Menururt Lovelock dan Wright, ada model 8P manajemen jasa terpadu yang menyoroti delapan variabel keputusan bagi manajer perusahaan jasa yaitu, Product, Place and Time, Process, Productivity and Quality, People, Promotion and Education, Phisycal Evidence, Price (Lovelock. C. H., 2005). Selan-jutnya, Ada yang menarik dari hasil penelitian yang dilakukan Ambarkahi yang secara tidak langsung melemahkan marketing mix sebagai faktor penunjang dalam me-ningkatkan brand Equity atupun keputusan calon mahasiswa dalam memilih perguruan tinggi (Ambarkahi, 2007). Penelitian Ambarkahi, menyimpulkan bahwa tidak semua faktor bauran pemasaran mempunyai pengaruh yang signifikan terhadap keputusan mahasiswa memilih kuliah di perguruan tinggi swasta (PTS) (Ambarkahi, 2007). Faktor yang tidak berpengaruh secara signifikan tersebut adalah faktor product dan people. Hasil penelitian Ambarkahi, tentu saja memberikan informasi pada kita bahwa tidak seluruh variabel bauran pemasaran jasa memiliki pengaruh secara signifikan terhadap keputusan calon mahasiswa untuk memilih perguruan tinggi (Ambarkahi, 2007). Selanjutnya Sofyandi, Hendri, dan Budi; Kalsum (2008) melakukan penelitian tentang penerapan marketing mix yang terdiri dari $7 \mathrm{P}$, product, price, place, promotion, people, physical evidence, dan process pada persepsi mahasiswa terhadap Perguruan tingggi di Bandung dan Medan. Berdasarkan penelitian yang mereka lakukan, ternyata strategi marketing mix secara simultan berpengaruh signifikan terhadap keputusan mahasiswa dalam memilih perguruan tinggi (Sofyandi, Hendri, Budi, 2008; Kalsum, 2008). Penelitian yang dilakukan Sofyandi dkk, (2008) dan Kalsum (2008) mematahkan hasil penelitian yang dilakukan oleh Ambarkasih (2007).

Untuk mengelaborasi strategi marketing mix, maka Lovelock dan Wright, (Lovelock. C. H. \&. W., 2005) membaginya ke dalam 8 kategori yaitu:

a) Product (Elemen Produk)

Banyak orang berfikir bahwa produk merupakan barang yang ditawarkan berupa barang yang terlihat secara kasat mata. Tetapi produk secara luas menawarkan kepuasan atas keinginan dan kebutuhan termasuk barang secara fisik, jasa, pengalaman, peristiwa, orang, tempat, organisasi, informasi, ataupun ide (Kotler, 2006). Selain itu, produk memuat semua komponen kinerja 
jasa yang menciptakan nilai bagi pelanggan (Lovelock. C. H. \&. W., 2005). Bagi pemakai jasa perguruan tinggi, produk dapat disimpulkan sebagai elemen terpenting dari sebuah jasa pendidikan, dengan upaya untuk memuaskan konsumen atas keinginan dan kebutuhannya yang bersifat tidak berwujud (intangible) dan hanya dapat dikonsumsi pada waktu yang bersamaan dengan partisipasi konsumen yang prosesnya tidak dapat disimpan (Kalsum, 2008). Dalam hal ini, jasa diarahkan pada tindakan intangible atau diarahkan pada mental manusia, yaitu pendidikan.

b) Place (Tempat)

Tempat merupakan keputusan manajemen mengenai kapan, dimana, dan bagaimana menyampaikan jasa kepada pelanggan. Pentingnya tempat atau lokasi tergantung pada jenis dan tingkat interaksi yang terlibat (Kalsum, 2008). Kotler dan Keller (2009) dalam bukunya yang berjudul Marketing Management menyatakan bahwa place (distribusi) mencakup aktivitas perusahaan untuk menyediakan produk bagi konsumen sasaran. Untuk penyediaan jasa pendidikan, maka interaksi penyedia jasa dengan pelanggan terdiri dari 2 interaksi yaitu, pelanggan mendatangi penyedia jasa, penyedia jasa mendatangi pelanggan atau pelanggan dan penyedia jasa mentransaksikan bisnis dalam jarak jauh.

c) Process (Proses)

Proses adalah metode pengoperasian atau serangkaian tindakan tertentu, yang umumnya berupa langkahlangkah yang diperlukan dalam suatu urutan yang telah ditetapkan (Lovelock. C. H. \&. W., 2005). Lingkungan fisik termasuk ke dalam bagian proses dari penyediaan jasa pendidikan. Lingkungan fisik menjadi faktor pendukung penentu keputusan calon mahasiswa dalam memilih perguruan tinggi yang akan dimasukinya. Diantaranya adalah proses yang dimulai dengan kunjungan untuk melihat bangunan, ruang kuliah, perpustakaan, laboratorium komputer dan manusia, dimana penyedia jasa dan konsumennya berinteraksi dan setiap komponen tangible memfasilitasi penampilan atau kounikasi jasa tersebut (Kalsum, 2008).

d) Productivity and Quality (Produktivitas dan Kualitas) Produktivitas adalah seberapa efisien pengubahan input jasa menjadi output yang menambah nilai bagi pelanggan. Sedangkan kualitas adalah sejauh mana suatu jasa memuaskan pelanggan dengan memenuhi kebutuhan, keinginan dan harapan mereka (Lovelock. C. H. \&. W., 2005). Hidayati, (Hidayati, 2008)dalam penelitiannya menyatakan bahwa analisis 
kualitas jasa pendidikan dapat membentuk citra layanan pada perguruan tinggi. Fokus dari kualitas adalah pada kepuasan pelanggan dimana kebutuhan, keinginan, dan harapan pemakai jasa dapat terpenuhi melalui jasa yang dikonsumsi dimana citra layanan tersebut dapat terbentuk dari faktor tanggung jawab dan mutu lulusan.

e) People (Orang)

Menururt Payne, (2003) people bagi pemasaran jasa menjadi sangat penting, keberhasilan memasarkan suatu jasa berkaitan erat dengan selection, training, motivation, dan management people. Orang adalah karyawan (dan kadangkadang pelanggan lain) yang terlibat dalam proses produksi (Lovelock. C. H. \&. W., 2005). Selanjutnya Kalsum, (2008) menyatakan bahwa yang termasuk kedalam people terdiri dari staff pengajar, staff administrasi, pustakawan dan teknisi, yang dimiliki oleh lembaga pendidikan tersebut yang memainkan peranannya selama proses komunikasi jasa berlangsung. Staff yang penuh perhatian, cekatan dan ramah dapat memberikan kepuasan kepada konsumen, oleh karena itu personil dan orang-orang yang profesional dalam bidangnya juga akan mempengaruhi keputusan calon mahasiswa dalam memilih perguruan tinggi (Ambarkahi, 2007). f) Promotion and Education (Promosi dan Edukasi)

(Lovelock. C. H. \&. W., 2005)mendefinisikan Promosi dan edukasi sebagai semua aktivitas dan alat yang menggugah komunikasi dan dirancang untuk membangun preferensi pelang-gan terhadap jasa dan penyedia jasa tertentu. Promosi yang menyangkut ketersediaan infor-masi mengenai administrasi dan registrasi perkuliahan turut menjadi faktor penentu dalam aktivitas promosi (Ridwansyah, 2008). Selain itu Dewanti dkk, (2007) melakukan penelitian bahwa brand aware-ness harus selalu ditingkatkan dengan melakukan brand recall, maka itu diperlukan pengelolaan promosi yang akan membantu perusahaan dalam menstimuli pembelian atas barang maupun jasa (Dewanti, 2007).

g) Phisycal Evidence (bukti fisik)

Bukti fisik adalah petunjuk visual atau berwujud lainnya yang memberikan bukti atas kualitas jasa. Bukti fisik dapat berupa fasilitas seperti gedung, kelas, laboratorium yang dimiliki Universitas, penampilan pegawai, dosen, staff dan manajemen Universitas yang secara langsung dapat dilihat oleh calon mahasiswa. Lingkungan fisik ini dapat mempengaruhi persepsi konsumen dan kualitas pelayananan jasa (Ambarkahi, 2007). 
h) Price (Harga dan Biaya Jasa Lainnya)

Harga merupakan pengeluaran uang, waktu dan usaha oleh pelanggan untuk membeli dan mengkonsumsi jasa (Lovelock. C. H. \&. W., 2005).Tetapi harga dapat hadir dengan berbagai bentuk dan berbagai macam fungsi seperti, sewa, biaya kuliah, ongkos, tarif, bea, biaya gaji dan komisi menjadi harga yang kita bayar sebagai usaha untuk mendapatkan barang maupun jasa yang kita butuhkan (Kotler, 2006), sehingga konsumen akan ber-sedia membayar lebih untuk suatu merek di atas produk-produk sejenis karena merek tersebut dipersepsikan mempu-nyai nilai lebih (value added) dibandingkan dengan komoditas generik (Dewi, 2005).

\section{Minat Beli}

Minat (interest) digambarkan sebagai suatu situasi seseorang sebelum melakukan suatu tindakan, yang dapat dijadikan dasar untuk memprediksi perilaku atau tindakan tersebut. Minat beli merupakan perilaku yang muncul sebagai respon terhadap objek yang menunjukkan keinginan pelanggan untuk melakukan pembelian (Kotler, 2006). Beberapa pengertian dari minat adalah sebagai berikut :

1) Minat dianggap sebagai sebuah perantara antara faktor-faktor motivasional yang mempengaruhi perilaku.
2) Minat juga mengindikasikan seberapa jauh seseorang mempunyai kemampuan untuk mencoba.

3) Minat menunjukkan pengukuran kehendak seseorang.

4) Minat berhubungan dengan perilaku yang terus-menerus.

Fishbein (dikutip oleh

Sumarwan, 2002) mengatakan bahwa minat dipandang sebagai sesuatu yang dengan segera mendahului tingkah laku yang ditentukan oleh komponen sosial atau norma subyektif yang dipertimbangkan dan digabungkan untuk mengevaluasi dan menyeleksi beberapa alternatif perilaku, guna memenuhi kebutuhan hidupnya.

Sedangkan menurut Anoraga (2000), minat beli merupakan suatu proses pengambilan keputusan yang dilakukan oelh konsumen dalam pembelian atas produk yang ditawarkan atau yang dibutuhkan oleh konsumen tersebut. Ada lima tahap dalam proses pengambilan keputusan untuk membeli yang umum dilakukan seseorang, yaitu: pengenalan kebutuhan, proses informasi konsumen, evaluasi produk atau merek, pembelian dan evaluasi pasca pembelian.

Menurut Peter dan Olson (2007), konsumen melakukan minat pembelian karena adanya suatu dorongan dan perilaku membeli secara berulang yang dapat menumbuhkan suatu kecenderungan untuk melakukan pembelian, setelah memperoleh respon positif atas tindakan masa lalu. 
Terdapat perbedaan antara pembelian aktual yang benar-benar dilakukan oleh konsumen dengan minat beli. Minat beli adalah kecenderungan pembelian untuk melakukan pembelian di masa mendatang, namun pengukuran terhadap kecenderungan terhadap pembelian umumnya dilakukan guna memaksimumkan prediksi terhadap pembelian aktual itu sendiri.

$$
\text { Dari uraian mengenai }
$$
pengertian minat beli diatas maka dapat disimpulkan bahwa minat beli adalah tahap kecenderungan perilaku membeli dari konsumen pada suatu produk barang atau jasa yang dilakukan pada jangka waktu tertentu dan secara aktif menyukai dan mempunyai sikap positif terhadap suatu produk barang atau jasa, didasarkan pada pengalaman pembelian yang telah dilakukan di masa lampau.

Minat beli merupakan kegiatan pembelian yang dilakukan oleh konsumen setelah mereka melakukan pembelian yang pertama kali. Menurut Engel, Blackwell, dan Miniard (2005), ada dua cara untuk mengukur minat perilaku membeli. Yang paling mudah adalah dengan menggantungkan pada pengalaman masa lalu. Sedangkan yang kedua, melalui pendekatan alternatif, yaitu dengan menanyakan konsumen. Dimana salah satu tipe minat konsumen adalah minat pembelian yang merefleksikan apakah konsumen mengantisipasi pembelian untuk produk atau merek yang sama lagi.

\section{Faktor-Faktor Yang Mempenga- ruhi Minat Beli}

Minat beli pada dasarnya merupakan suatu pembelian secara subyektif dalam diri setiap individu terhadap hal-hal yang berhubungan secara langsung dengan transaksi ekonomi. Ada beberapa faktor utama yang mempengaruhi minat seseorang untuk melakukan pembelian (dikutip pada penelitian peter dan irawan, 2008 melalui http://digilib.petra.ac.id/jiunkpe-nss1-2008-31401489-9628-high_endchapter2.pdf), yaitu:

\section{1) Faktor Psikologis}

Meliputi pengalaman belajar individu tentang kejadian di masa lalu, serta pengaruh sikap dan keyakinan individu. Pengalaman belajar dapat didefinisikan sebagai suatu perilaku akibat pengalaman sebelumnya. Timbulnya niat konsumen untuk melakukan pembelian ulang sangat dipengaruhi oleh pengalaman belajar individu dan pengalaman belajar konsumen. Hal ini dapat dipelajari dari beberapa teori berikut ini :

a) Teori Stimulus Respon

Berdasarkan teori stimulus respon dari B.F.Skinner, dapat disimpulkan bahwa konsumen akan merasa puas jika mendapatkan produk, merek, dan layanan diperoleh konsumen dengan tidak menyenangkan, akan menjadikan konsumen merasa tidak puas.

b) Teori Kognitif 
Berdasarkan teori kognitif dari Heider dan Festinger, perilaku kebiasaan merupakan dari akibat proses berpikir dan orientasi dalam mencapai suatu tujuan. Berdasarkan teori ini dapat disimpulkan bahwa keputusan konsumen sangat dipengaruhi oelh memorinya terhadap sesuatu yang terjadi pada masa lampau, masa sekarang, dan masa yang akan datang.

c) Teori Gestalt dan Teori Lapangan

Berdasarkan teori gestalt dan teori lapangan, dapat disimpulkan bahwa faktor lingkungan merupakan kekuatan yang sangat berpengaruh pada niat konsumen untuk mengadakan suatu pembelian. Penggunaan objek secara keseluruhan akan lebih baik daripada hanya bagian-bagiannya saja. Misalnya, melayani pembeli secara sempurna, dari awal konsumen masuk pada suatu rumah makan sampai pada saat ia meninggalkan rumah makan tersebut, akan meninggalkan penilaian positif di mata konsumen.

2) Faktor Pribadi

Kepribadian konsumen akan mempengaruhi persepsi dan pengambilan keputusan dalam membeli. Oleh karena itu, peranan pramuniaga toko penting dalam memberikan pelayanan yang baik bagi konsu- men. Faktor pribadi ini termasuk dalam konsep diri. Konsep diri dapat didefinisikan sebagai cara kita melihat diri sendiri dan dalam waktu tertentu sebagai gambaran tentang upah yang kita pikirkan. Dalam hubungan dengan repurchase intention, produsen perlu menciptakan situasi yang sesuai dengan yang diharapkan oleh konsumen.

3) Faktor Sosial

Mencakup faktor kelompok anutan (small reference group). Kelompok anutan didefinisikan sebagai suatu kelompok orang yang mempengaruhi sikap, pendapat, norma, dan perilaku konsumen. Kelompok anutan ini merupakan kumpulan keluarga, kelompok atau orang tertentu. Kotler (2007) "mengatakan bahwa anggota keluarga merupakan kelompok acuan primer yang paling berpengaruh. Pengaruh kelompok anutan terhadap repurchase intention antara lain dalam menentukan produk dan merek yang mereka gunakan yang sesuai dengan aspirasi kelompoknya".

\section{Perguruan Tinggi di Indonesia}

Pendidikan tinggi di Indonesia mengalami perubahan panorama selama dekade terakhir ini. Perubahan panorama yang dimaksud meliputi perubahan paradigma, perubahan pengelolaan, perubahan persaingan, dan sebagainya. Perubahan paradigma terutama dipicu oleh perkembangan teknologi informasi sehingga e- 
learning, e-university dan sejenisnya mulai banyak dibicarakan dan diusahakan. Perubahan pengelolaan menyangkut badan penyelenggara pendidikan tinggi, baik yang diselenggarakan pemerintah maupun swasta (Indrajit, 2004).

Indrajit dan Djokopranoto, (Indrajit, 2004) dalam bukunya Manajemen Perguruan Tinggi Modern berpen-dapat bahwa Perguruan tinggi tidak hanya perlu dilihat sebagai pusat ilmu pengetahuan, pusat penelitian, dan pusat pengabdian masyarakat, tetapi juga suatu entitas korporat 'penghasil ilmu pengetahuan' yang perlu 'bersaing' untuk menjamin kelangsungan hidup. Persaingan, sebagai mana dialami oleh perusahaan for profit, meliputi persaingan dibidang mutu, harga, dan layanan. Situasi persaingan yang ketat ini menyebabkan banyak perguruan tinggi mengalami banyak kesulitan untuk meningkatkan jumlah mahasiswanya. Sementara itu calon mahasiswa memiliki kemudahan dalam memilih nama perguruan tinggi yang dapat memenuhi keinginannya (Andre, 2009). Perguruan tinggi sebagai suatu entitas non profit, juga menghadapi hal yang sama. Untuk pengelolaan semua itu, maka diperlukan pengetahuan dan ketrampilan manajemen, yaitu manajemen perguruan tinggi.

Peraturan Pemerintah Nomor 60 Tahun 1999 tentang Pendidikan Tinggi mengatur bahwa penyelenggara perguruan tinggi yang dilakukan oleh masyarakat haruslah berbentuk yayasan atau badan yang bersifat sosial. ketentuan ini dimaksudkan untuk memberikan status badan hukum pada penyelenggara pendidikan tinggi. Jadi ada semacam penjenjangan dalam penyelenggaraan perguruan tinggi swasta yaitu, jenjang pertama Universitas dan jenjang ke dua Yayasan. Untuk perguruan tinggi negeri, perguruan tinggi itu sendiri sudah merupakan Badan Hukum Milik Negara (BHMN) yang bersifat nirlaba, sejajar dengan Badan Usaha Milik Negara (BUMN).

Dalam perkembangannya, perguruan tinggi milik swasta juga memiliki semacam badan hukum tersendiri. Motivasi ini didorong oleh penilaian bahwa dengan adanya dua jenjang penyelenggaraan perguruan tinggi swasta, terdapat birokrasi yang tinggi sehingga menghambat kelincahan gerak perguruan tinggi swasta. Dengan dijadikannya perguruan tinggi swasta menjadi badan hukum sendiri, maka perguruan tingi swasta dapat bertindak lebih mandiri, otonom, dan tidak memerlukan lagi badan hukum lain sebagai cantolannya (Indrajit, 2004).

Semakin berkembangnya perubahan zaman, orientasi sistem pendidikan, dan permintaan akan tenaga kerja terdidik, maka akan tercipta sebuah perubahan yang sangat besar pada setiap organisasi pendidikan. Globalisasi yang terjadi telah memaksa setiap individu dan organisasi dimanapun untuk 
melakukan transformasi diri. Maka itu, model pengelolaan perguruan tinggi dapat disetarakan dengan model bisnis jasa. Model bisnis ini termasuk kedalam proses pemasaran, dimana Dharmmesta mendefinsikan pemasaran sebagai: kegiatan-kegiatan pokok yang dilakukan oleh perusahaan untuk mempertahankan kelangsungan hidupnya, dan mendapatkan laba" (Dharmmesta, Manajemen Pemasaran Analisa Prilaku Konsumen, 1997). Lebih lanjut Kotler dan Keller mendefinisikan definisi pemasaran terkini sebagai proses kemasyarakatan yang dilakukan individu dan kelompok untuk memperoleh apa yang mereka butuhkan dan inginkan melalui penciptaan, penawaran dan pertukaran secara bebas produk dan jasa nilai dengan pihak lain (Kotler dan Keller, 2009:45).

Dengan dimasukannya pengelolaan perguruan tinggi ke dalam model pegelolaan bisnis jasa, maka perguruan tinggi tidak hanya melakukan pemasaran eksternal, tetapi juga pemasaran internal dan pemasaran interaktif dengan melibatkan mahasiswa dan sumber daya manusia yang dimiliki (Kotler
P. , 1997). Pemasaran interaktif yang dimaksud adalah dengan lingkungan individu mahasiswa yang terdiri dari budaya, kelas sosial, kelompok referensi dan keluarga. Selanjutnya kepuasan stakehoder (mahasiswa, dosen, staff dan pengelola) juga menjadi ukuran keberhasilan perguruan tinggi dalam mengelola manajemennya serta tetap mengutamakan mutu akademik sebagai produk jasa yang harus dicapai (Sembiring, 2009). Dengan begitu, banyak perguruan tinggi terus berusaha untuk mengevaluasi pelayanannya dengan menggunakan metode kualitatif maupun metode kuantitaif sebagai upaya untuk mendapatkan respon dari maha-siswanya (Pratminingsih, 2006).

\section{METODE PENELITIAN}

Dengan mempelajari tinjauan pustaka dari beberapa dasar teori yang ada serta berdasarkan pada rumusan masalah yang telah dijelaskan dalam pembahasan Pendahuluan sebelumnya, maka kerangka pemikiran dalam penelitian karya akhir ini digambarkan pada Gambar 4.1 berikut ini: 


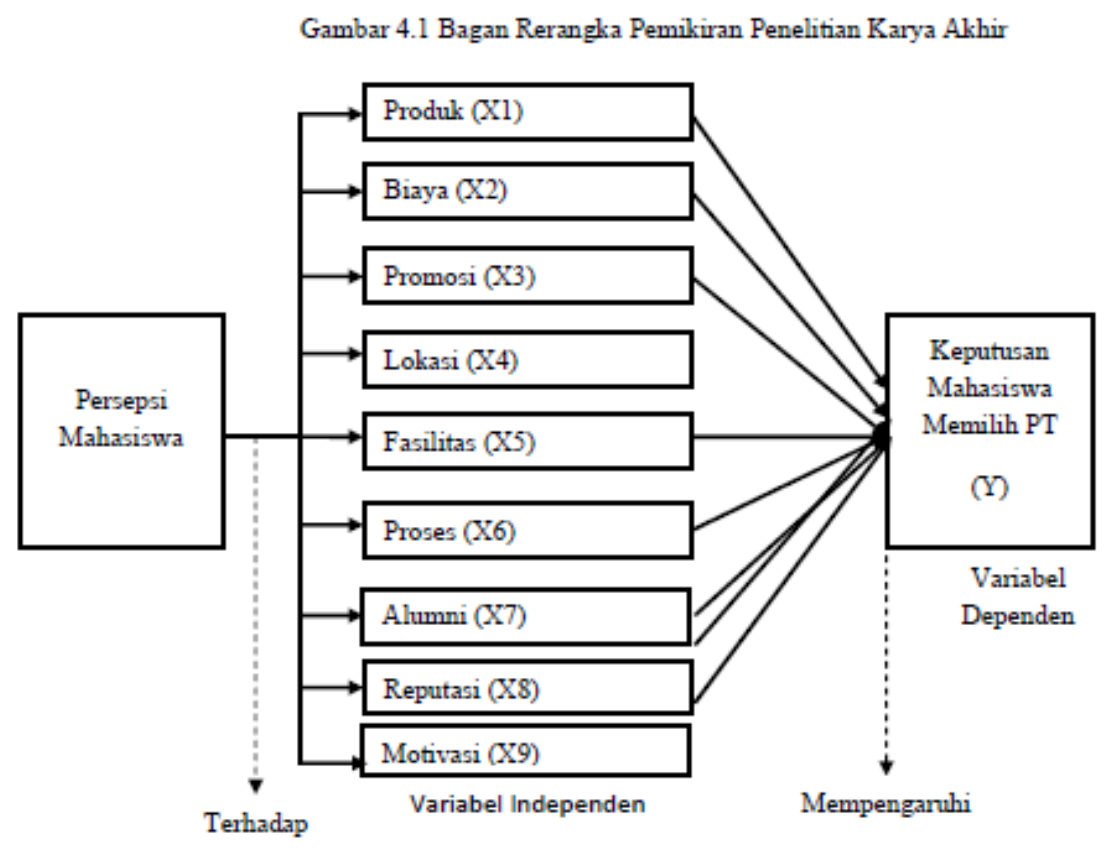

Dalam melakukan penelitian ini, teknik pengumpulan data sebagai berikut:

1. Wawancara (interview) dilakukan langsung kepada pihak yang berhak/berwenang memberikan informasi/data secara sistematis dasarkan tujuan penelitian pimpinan, pegawai, dan dosen IPWIJA

2. Daftar pertanyaan (quetionaire) diberikan langsung kepada mahasiswa yang menjadi responden dalam penelitian ini

3. Studi dokumentasi dengan mengumpulkan dan mempelajari data atau dokumen yang mendukung penelitian ini yaitu jumlah mahasiswa IPWIJA dari tahun 2005 sampai 2011, jumlah lulusan S1dari tahun 2005 sampai 2012 dan lainnya.
4. Dalam penelitian ini, pihak yang menjadi responden ialah mahasiswa S2 Program Megister Manajemen IPWIJA Angkatan 49, 50 dan 51.

Penelitian ini dikarenakan jumlah populasinya tidak dapat ditentukan jumlahnya secara pasti dan hanya berdasarkan asumsi peneliti, maka teknik pengambilan sampel yang digunakan termasuk dalam kategori penarikan sampel Non-Probabilitas (Non-Probability Sampling) yaitu suatu prosedur penarikan sampel yang bersifat subyektif, dalam hal ini probabilitas pemilihan elemen-elemen populasi tidak dapat ditentukan. Hal ini disebabkan setiap elemen populasi tidak memiliki peluang yang sama untuk dipilih sebagai sampel $(\mathrm{H}$, 2004). 
Metode pengambilan sampel yang digunakan adalah metode convenience (convenience sampling), yaitu suatu metode di mana sampel dipilih karena mudah dijangkau. Sampel convenience merupakan metode sampel non probabilitas, di mana tiap unit populasi tidak memiliki kesempatan untuk dipilih sebagai sampel penelitian. Dengan kata lain sampel diambil atau terpilih karena sampel tersebut berada pada waktu dan tempat yang tepat. Untuk menentukan ukuran sampel dari suatu populasi digunakan rumus Slovin yang dikutip Sugiyono (2007). Berdasarkan persamaan Slovin, peneliti ingin menduga proporsi besarnya sample responden mahasiswa S2 program Megister Manajemen IPWIJA angakatan 49, 50 dan 51 yang akan diteliti dari populasi sebesar $150(\mathrm{~N})$ mahasiswa, asumsi populasi ini diambil dari (50 mahasiswa dalam satu kelas $\times 3$ kelas).
Presisi ditetapkan diantara $5 \%$ (e) dengan tingkat kepercayaan $95 \%$, maka besarnya sample sebanyak 110 calon responden yang akan menjadi jumlah objek yang akan diteliti.

Tehnik analisis data yang digunakan dalam penelitian ini adalah tehnik analisis kuantitatif yaitu analisis terhadap data yang diberikan skor sesuai dengan skala pengukuran yang telah menggunakan formula-formula statistik.

\section{hASIL PENELITIAN}

Pengaruh Variabel X1(Produk), X2 (Biaya), X3 (Promosi), X4 (Lokasi), X5 (Fasilitas), X6 (Proses), X7 (Alumni), X8 (Reputasi), X9 (Motivasi) secara simultan terhadap Variabel Y (Keputusan).

Hasil perhitungan dengan analisis regresi linier berganda dapat dilihat pada tabel berikut: 


\begin{tabular}{|c|c|c|c|}
\hline \multicolumn{4}{|c|}{ Tabel 1} \\
\hline \multicolumn{4}{|c|}{ Hasil Uji Regresi Linier Berganda } \\
\hline Variabel & Koefisien Regresi & Beta & Sig \\
\hline Konstanta & 0.921 & & \\
\hline Produk $\mathrm{X}_{1}$ & 0.473 & 0.657 & 0.000 \\
\hline Biaya $X_{2}$ & -0.004 & -0.006 & 0.962 \\
\hline Promosi $X_{3}$ & -0.064 & -0.134 & 0.265 \\
\hline Lokasi $\mathrm{X}_{4}$ & -0.170 & -0.342 & 0.036 \\
\hline Fasilitas $X_{5}$ & -0.023 & -0.035 & 0.834 \\
\hline Proses $\mathrm{X}_{6}$ & 0.027 & 0.029 & 0.840 \\
\hline Alumni $X_{7}$ & -0.066 & -0.099 & 0.449 \\
\hline Reputasi $X_{8}$ & -0.114 & -0.175 & 0.386 \\
\hline Motivasi X9 & -0.014 & -0.014 & 0.909 \\
\hline$R_{2}=0.652$ & $F=3.817$ & Sig $=0.00 C$ & \\
\hline Sumber: Hasil Penelitian, 2013 & & & \\
\hline
\end{tabular}

Dari tabel di atas dapat diketahui persamaan regresi linier berganda, $F$ hitung dan probabilitas (signifikansi) hasil perhitungan. Persamaan regresi dapat dibentuk dari kolom Unstandardized Coefficients yaitu pada kolom B, dimana dari nilai yang ada pada Unstandardized Coefficients yaitu pada kolom B dapat dibuat persamaan regresi berganda yaitu :

$\breve{Y}=0.921+0.473 \mathrm{X} 1+-0.004 \mathrm{X} 2$

$+-0.064 \times 3+-0.170 \times 4+-0.023$

$\mathrm{X} 5+0.027 \mathrm{X} 6+-0.066$

$X 7+-0.114 X 8+-0.014 X 9$

Untuk mengetahui signifikansi atau tidaknya pengaruh variabel X1(Produk), X2 (Biaya), X3 (Promosi), $\quad X 4 \quad$ (Lokasi), $\quad \mathrm{X5}$ (Fasilitas), X6 (Proses), X7 (Alumni), X8 (Reputasi), X9 (Motivasi) terhadap variabel $Y$ (Keputusan) maka dilakukan uji signifikansi dengan melihat $F$ hitung dan atau probabilitas (Sign.). Data hasil perhitungan dalam tabel diatas dapat dijelaskan sebagai berikut :

a. Dalam persamaan regresi linier berganda $\breve{Y}=0.921+0.473 \times 1$ $+-0.004 \times 2+-0.064 \times 3+-$ $0.170 \times 4+-0.023 \times 5+0.027$ $\mathrm{X} 6+-0.066 \mathrm{X7}+-0.114 \mathrm{X} 8+-$ $0.014 \times 9$ memiliki nilai konstanta $\mathrm{a}=0.921$ dengan $\mathrm{F}$ hitung $=$ 3.817 dan probabilitas Sig. = 0.000 , karena nilai probabilitas Sig. lebih kecil dari taraf uji a $(0.000<0.05)$, maka HO ditolak dan $\mathrm{Ha}$ diterima atau dibandingkan dengan $\mathrm{F}$ tabel .

b. Dalam persamaan regresi linier berganda $\breve{Y}=0.921+0.473 \times 1$ $+-0.004 \times 2+-0.064 \times 3+-$ $0.170 \times 4+-0.023 \times 5+0.027$ $\mathrm{X} 6+-0.066 \mathrm{X7}+-0.114 \mathrm{X} 8+-$ $0.014 \times 9$ memiliki nilai konstanta $\mathrm{a}=0.921$ juga memiliki nilai $\mathrm{R}$

Available at:

http://journal.unj.ac.id/unj/index.php/econosains/article/view/1107 
sebesar 0.807 dan R2 senilai 0.652

\section{KESMPULAN}

Pengaruh Variabel X1 (Produk), X2 (Biaya), X3 (Promosi), X4 (Lokasi), X5 (Fasilitas), X6 (Proses), X7 (Alumni), X8 (Reputasi), X9 (Motivasi) secara simultan terhadap Variabel Y (Keputusan) ditunjukan dengan nilai R2 sebesar 0.652 dengan persamaan regresi linier berganda $\breve{Y}=0.921+0.473 \times 1+-$ $0.004 \times 2+-0.064 \times 3+-0.170 \times 4$ $+-0.023 \times 5+0.027 \times 6+-0.066$ $X 7+-0.114 X 8+-0.014 X 9$.

Hasil pengujian regresi berganda dengan uji $F$ bahwa pengaruh variabel $\mathrm{X} 1$ (Produk), X2 (Biaya), X3 (Promosi), X4 (Lokasi), X5 (Fasilitas), X6 (Proses), X7 (Alumni), $\quad$ X8 (Reputasi), $\quad$ X9 (Motivasi) secara simultan terhadap Variabel Y (Keputusan) ternyata signifikan yaitu nilai $\mathrm{F}$ hitung lebih besar nilai $\mathrm{F}$ tabel $=1.93$.

\section{Saran}

Setelah melihat dari hasil penelitian pada analisis yang telah dilakukan, maka penulis mencoba mengemukakan rekomendasi sebagai berikut :

1) Agar dapat meningkatkan persepsi mahasiswa dalam keputusan memilih perguruan tinggi IPWIJA harus memperhatikan dan menerapkan strategi pemasaran yang tepat dalam hal strategi penawaran harga (biaya) yang disesuaikan dengan kemampuan rata-rata calon mahasiswa atau jika memungkinkan maka sebaiknya dilakukan penelitian untuk meneliti perkiraan penetapan harga minimal biaya yang sesuai untuk memasarkan perguruan tinggi IPWIJA dan disesuaikan pula dengan manfaat yang akan diterima oleh mahasiswa apabila mengikuti kuliah sesuai dengan harapan yang didapat.

2) Selain itu sebaiknya kemampuan dan keahlian staf pengajar dalam hal penyampaian materi terus ditingkatkan agar dapat lebih meningkatkan mutu pendidikan itu sendiri.

3) Dikarenakan bukti fisik merupakan salah satu faktor yang berpengaruh signifikan terhadap keputusan mahasiswa, maka sebaiknya media brosur dan proposal ilustrasi produk dapat didesain lebih menarik, informatif dan berkualitas untuk lebih meningkatkan persepsi mahasiswa dalam memilih perguruan tinggi IPWIJA program S2.

\section{DAFTAR PUSTAKA}

Ambarkahi, Y. (2007). Faktor Bauran Pemasaran Jasa Yang Dipertimbangkan Mahasiswa Dalam Memilih Kuliah di Politeknik Negeri Jember. Jurnal Bisnis dan Manajemen, 339-347.

Dewanti, R. M. (2007). Analisis Brand Equity Bina Nusantara University Dilingkungan SMU 
Jakarta. Journal The Winner, 197-213.

Dharmmesta, B. (1997). Manajemen Pemasaran Analisa Prilaku Konsumen. Yogyakarta: BPFE.

Dharmmesta, B. (1997). Manajemen Pemasaran Analisa Prilaku Konsumen. Yogyakarta: BPFE.

H, K. (2004). Hermawan Kertajaya on Brand. Bandung: Mizan Media Utama .

Hidayati, M. \&. (2008). Analisis Kualitas Jasa Pendidikan yang Membentuk.

Indrajit, E. \&. (2004). Manajemen Perguruan Tinggi Modern. Jakarta: STIMIK Perbanas.
Kotler, P. \&. (2006). Marketing Management 12th edition. New Jersey: Prentice Hall.

Kotler, P. (1997). Manajemen Pemasaran Analisis Perencanaan, Implementasi dan Kontrol.

Lovelock. C. H., \&. W. (2005). Manajemen Pemasaran Jasa. Jakarta: PT. Indeks Kelompok Gramedia .

Lovelock. C. H., \&. W. (2005). Manajemen Pemasaran Jasa. Jakarta: PT. Indeks Kelompok Gramedia.

Ridwansyah, I. \&. (2008). Pengaruh Bauran Pemasaran Jasa Pendidikan Tinggi .

Sembiring, F. (2009). Analisis Pengaruh Bauran Pemasaran Terhadap Kualitas Jasa . 